\title{
Intensitas Modal Perusahaan dan Tax Avoidance pada Perbankan Nasional
}

\author{
Erma Wulan Sari", Rihan Mustafa Zahri \\ Fakultas Ekonomi dan Bisnis, D3 Manajemen Pajak, Universitas PGRI Madiun, Madiun, Indonesia \\ Email: 1,"*ermawulansari@unipma.ac.id, ${ }^{2}$ rihanmustafa@unipma.ac.id \\ Email Penulis Korespondensi: ermawulansari@unipma.ac.id \\ Submitted: 19/11/2021; Accepted: 29/11/2021; Published: 30/11/2021
}

\begin{abstract}
Abstrak-Penelitian ini bertujuan untuk menguji pengaruh capital intensity ratio, ukuran perusahaan dan kepemilikan institusional terhadap praktik tax avoidance. Variabel terikat yang digunakan dalam penelitian ini adalah tax avoidance sedangkan variabel bebas yang digunakan adalah capital intensity ratio, ukuran perusahaan dan kepemilikan institusional. Populasi dalam penelitian ini adalah selurih perusahaan perbankan yang terdaftar di BEI pada tahun 2016-2020. Sedangkan teknik pengambilan sampel dalam penelitian ini adalah purposive sampling diperoleh total sampel 32 perusahaan. Teknik analisis data dalam penelitian ini adalah mengunakan analisis regresi berganda. Hasil penelitian menunjukkan bahwa capital intensity ratio berpengaruh terhadap tax avoidance sedangkan ukuran perusahaan dan kepemilikan institusional tidak berpengaruh terhadap tax avoidance.
\end{abstract}

Kata Kunci: Capital Intensity Ratio; Ukuran Perusahaan; Kepemilikan Institusional; Tax Avoidance

Abstract-This study aims to examine the effect of capital intensity ratio, firm size and institutional ownership on tax avoidance practices. The dependent variable used in this study is tax avoidance, while the independent variables used are capital intensity ratio, firm size and institutional ownership. The population in this study are banking companies listed on the IDX in 2016-2020. While the sampling technique in this study is purposive sampling obtained a total sample of 32 companies. The data analysis technique in this research is using multiple regression analysis. The results showed that capital intensity rtaio had an effect on tax avoidance, while firm size and institutional ownership had no effect on tax avoidance.

Keywords: Capital Intensity Ratio; Firm Size; Institusional Ownership; Tax Avoidance

\section{PENDAHULUAN}

Kemajuan sebuah Negara dapat terlihat dari pendapatan perkapita dan Indeks Pembangunan Manusia. Pendapatan terbesar negara Indonesia adalah berasal dari sektor pajak. Pajak memiliki peran penting dalam kemajuan Indonesia. Tidak ada negara merdeka di mana pun di dunia yang tidak mengumpulkan penerimaan dari pajak. Berdasarkan UU No 28 Tahun 2007 tentang ketentuan umum dan tata cara perpajakan yang dimaksud dengan pajak adalah "kontribusi wajib kepada negara yang terutang oleh orang pribadi atau badan yang bersifat memaksa berdasarkan Undang Undang, dengan tidak mendapat timbal balik secara langsung dan digunakan untuk keperluan negara bagi sebesar-besarnya kemakmuran rakyat". Bagi negara, pajak merupakan salah satu sumber pendapatan negara, sedangkan bagi perusahaan, pajak adalah biaya yang harus dikeluarkan sehingga dapat mengurangi laba bersih. Perbedaan kepentingan antara negara yang mengharapkan penerimaan pajak yang besar bertolak jauh dengan keinginan perusahaan yang meinginkan pembayaran pajak seminimal mungkin (Setia, 2015). Oleh karena itu dengan adanya perbedaan kepentingan tersebut banyak perusahaan yang berupaya untuk melakukan pengurangan atau pengehematan pajak bagi persahaan atau sering dikenal dengan istilah Tax avoidance.

Menurut Kalbuana et al., (2017) Tax avoidance atau penghindaran pajak adalah usaha yang dilakukan untuk mengecilkan pajak terutang yang masih bersifat legal, namun menimbulkan resiko bagi perusahaan, baik dikenakan denda oleh pemerintah, serta reputasi yang buruk dimata masyarakat. Sedangkan menurut Susilowati et al., (2020) tax avoidance merupakan suatu cara untuk menekan beban pajak yang ditanggung perusahaan secara legal yang tidak melanggar peraturan perpajakan karena dalam peraturan perpajakan diperbolehkan adanya tax avoidance. Dengan diperbolehkan praktik tax avoidance banyak perusahaan yang memanfaatkan celah ini untuk mengurangi beban pajak yang harus dibayarkan.

Terdapat beberapa faktor penyebab perusahaan bertindak lebih agresif dalam melakukan praktik tax avoidance. Salah satu faktor penyebabnya adalah Capital Intensity Ratio atau sering disebut dengan intensitas modal. capital intensity ratio merupakan rasio yang menggambarkan aktivitas investasi yang dilakukan oleh perusahaan yang dikaitkan dengan investasi dalam bentuk aset tetap (intensitas modal) Damayanti \& Gazali (2018). Rasio intensitas modal ini sangat penting bagi manajemen perusahaan karena rasio intensitas modal dapat menunjukkan tingkat efisiensi perusahaan dalam menggunakan aktivanya untuk menghasilkan penjualan. Intensitas modal dapat dijadikan teknik atau cara oleh perusahaan untuk menghindari beban pajak, hal ini dikarenakan manajemen pada suatu perusahaan dapat memanfaatkan dana yang menganggur untuk membeli aset tetap. Aset tetap tersebut akan mengalami penyusutan pada setiap tahunnya, sehingga akan menimbulkan beban penyusutan yang dapat mengurangi beban perpajakan perusahaan tersebut. Penelitian tentang capital intensity ratio telah dilakukan oleh Purwanti \& Sugiyarti (2017), Rahmawati (2019), dan Penelitian yang dilakukan oleh (Anggraini et al., 2020) dan Cahyani et al., (2021), dimana hasil dari penelitian tersebut menyatakan bahwa Capital Intensity Ratio memiliki pengaruh terhadap tax avoidance. Sedangkan hal berbeda terjadi pada penelitan yang dilakukan oleh 
Puspita dan Febrianti (2017), (Rahman \& Tjetje, 2018) dan (Tebiono \& Sukadana, 2019) menyatakan bahwa Capital Intensity Ratio tidak memiliki pengaruh terhadap tax avoidance.

Ukuran perusahaan merupakan angka yang bisa mencerminkan besar ataupun kecilnya perusahaan (brigham, 2013). Perusahaan yang besar adalah perusahaan yang memiliki total aset yang semakin bertambah dan diikuti dengan tingkat laba yang semakin meningkat. Menurut Hidayah et al., (2020) perusahaan dengan ukuran besar akan mendapatkan perhatian lebih dari fiskus karena dianggap lebih mampu dalam menciptakan laba yang besar sehingga perusahaan juga harus menanggung beban pajak yang tinggi. Dengan beban pajak tinggi yang ditanggung oleh perusahaan, maka perusahaan akan melakukan berbagai cara untuk melakukan parktik tax avoidance guna meminimalisasi pajak yang akan dibayar. Menurut Puspita \& Febrianti (2018) Semakin besar suatu perusahaan maka perusahaan akan lebih berani untuk menggunakan pinjaman yang semakin besar pula. Semakin besar jumlah hutang yang digunakan sebagai sumber pendanaan, maka akan semakin besar pula biaya atau beban bunga yang menjadi pengurang penghasilan kena pajak. Dengan demikian, pajak penghasilan terhutang atau jumlah pajak yang terhutang menjadi semakin kecil. Jadi semakin besar ukuran perusahaan maka semakin besar pula perusahaan akan melakukan praktik tax avoidance. Penelitian dari Oktagiani (2015) dan Puspita \& Febrianti (2018) menyatakan bahwa ukuran perusahaan berpengaruh signifikan terhadap tax avoidance. Sedangkan penelitian dari Susilowati et al., (2020) menyatakan bahwa ukuran perusahaan tidak berpengaruh terhadap tax avoidance.

Kepemilikikan institusional merupakan kepemilikan saham yang dimiliki oleh pemerintah, perusahaan asuransi, investor badan luar negeri atau bank (Dewi \& Jati, 2014). Menurut Karim (2017) kepemilikan institusional memiliki arti penting dalam memonitor manajemen perusahaan karena adanya kepemilikan institusional akan meningkatkan pengawasan yang lebih optimal karena dianggap mampu memonitor setiap keputusan yang diambil oleh para manajer secara efektif. Sedangkan Moeljono (2020) berpendapat bahwa kepemilikan institusional diduga sebagai salah satu faktor praktik penghindaran pajak hal ini dikarenakan mampu mengintervensi kebijakan manajemen. Hasil penelitian dari Winata (2014) menyatakan bahwa kepemelikian isntitusional tidak berpengaruh terhadap tax avoidance. Sedangkan hasil penelitian dari Cahyono et al., (2016) Cahyono (2016), penelitian dari Karim (2017) berpendapat bahwa kepemilikan institusional berpengaruh negative terhadap praktix tax avoidance.

Penelitian ini dimotivasi dengan maraknya kasus praktik tax avoidance yang dilakukan oleh perusahaanperusahaan besar dan ternama. Praktik tax avoidance kemungkinan besar dapat dilakukan oleh banyak perusahaan salah satunya pada sektor perbankan. Transaksi bank di Indonesia tidak hanya terjadi antar daerah di dalam negeri, melainkan dapat pula terjadi transaksi dengan negara lain atau biasa disebut transaksi lintas Negara. Tidak dapat dipungkiri bahwa transaksi lintas negara tersebut dapat pula terjadi antara pihak yang memiliki hubungan istimewa (perusahaan afiliasi). Atas kegiatan bisnis lintas negara yang dilakukan oleh perusahaan atau dalam hal ini bank yang memiliki hubungan istimewa, dapat dimungkinkan atau memiliki kemungkinan paling buruk dilakukan praktik penghindaran pajak atau tax avoidance. Selain itu adanya hasil perbedaan terhadap penelitian sebelumnya mengenai praktik tax avoidance juga menjadi konsep dasar penelitian ini dilakukan.

Berdasarkan latar belakang penelitian maka dapat dikemukakan beberapa masalah penelitian sebagai berikut apakah capital intensity ratio, ukuran perusahaan dan kepemilikan institusional berpengaruh terhadap tax avoidance, (Studi Empiris pada perusahaan Perbankan yang terdaftar di Bursa Efek Indonesia (BEI) Tahun 2016-2020. Berdasarkan rumusan masalah tersebut maka tujuan dilakukannya penelitian ini yaitu untuk mengetahui pengaruh capital intensity ratio, ukuran perusahaan dan kepemilikan institusional terhadap tax avoidance (Studi Empiris pada perusahaan Perbankan yang terdaftar di Bursa Efek Indonesia (BEI) Tahun 2016-2020. Manfaat dari penelitian ini adalah untuk memberikan informasi khususnya dalam bidang perpajakan yang berkaitan dengan praktik Tax Avoidance di Indonesia sehingga dapaat dijadikan bahan pertimbangan dalam menentukan keputusan berinvestasi khususnya pada perusahaan perbankan yang terdaftar di Bursa Efek Indonesia (BEI).

\section{METODE PENELITIAN}

\subsection{Kerangka Dasar Penelitian}

Penelitian ini dapat dimasukkan dalam jenis penelitian kuantitatif. Penelitian kuantitatif adalah metode penelitian yang berlandaskan pada filsavat positifisme, digunakan untuk meneliti pada populasi atau sampel tertentu, pengumpulan data menggunakan instrument penelitian, analisis data bersifat kuantitatif/ statistic dengan tujuan menguji hiotesis yang telah ditetapkan (Sugiyono, 2011). Adapun subjek dalam penelitian ini adalah laporan keuangan perusahaan yang terdaftar di BEI Sedangkan Objek penelitian ini adalah perusahaan perbankan yang terdaftar di BEI. Tujuan dari penelitian ini yaitu untuk mengetahui pengaruh dari Capital Intensity Ratio, Ukuran Perusahaan dan kepemilikan Institusional terhadap Praktik Tax Avoidance. Desain penelitian dapat disajikan pada gambar berikut: 


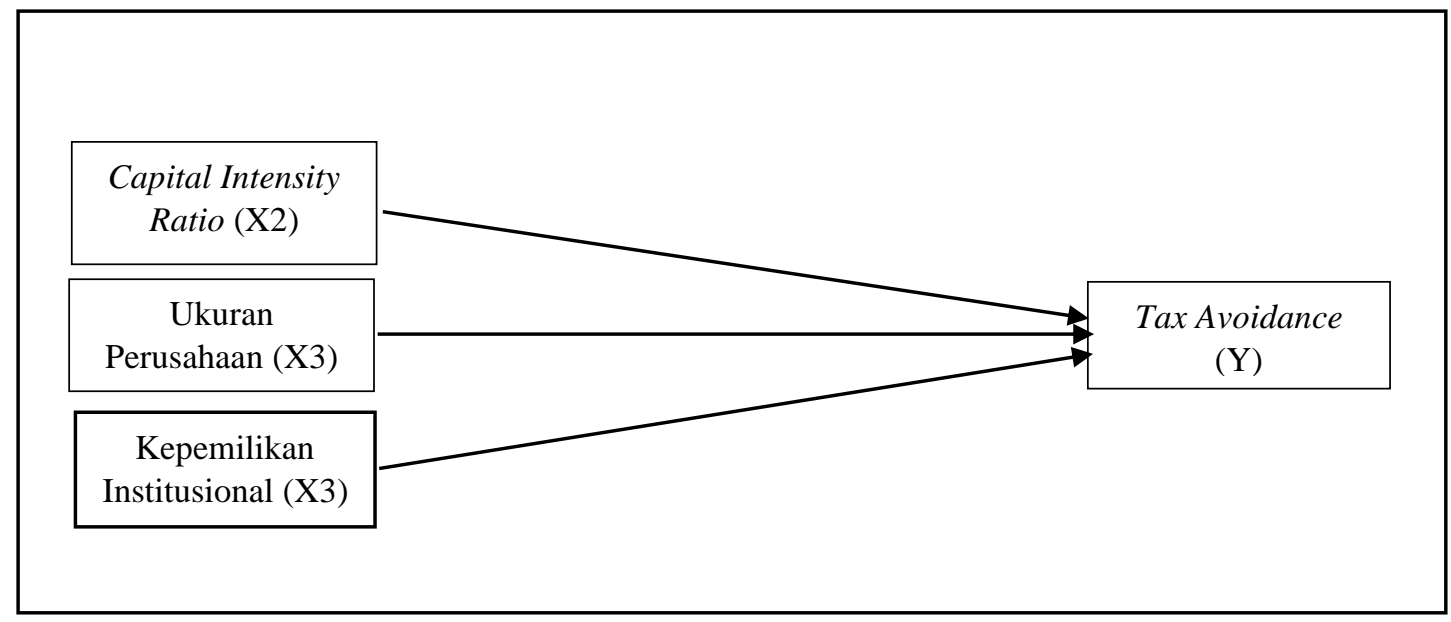

Gambar 1. Desain Penelitian

\subsection{Populasi dan Sampel}

Populasi yang digunakan dalam penelitian ini adalah seluruh perusahaan perbankan yang terdaftar di BEI pada tahun 2016-2020. Adapun teknik pengambilan sampel yang digunakan adalah purposive sampling. Menurut (Sugiyono, 2011) purposive sampling adalah teknik penentuan sampel dengan melakukan pertimbangan tertentu. Adapun kriteria pengambilan sampel dalam penelitian ini adalah sebagai berikut: (1) Perusahaan perbankan yang terdaftardi BEI Th 2016-2020, (2) Perusahaan perbankan yang tidak mengalami kerugian (memiliki profit) Th 20162020, (3) perusahaan perbankan yang secara konsisten mempublikasikan laporan keungan selama periode 20162020. Setelah dilakukan pengambilan sampel maka jumlah sampel yang digunakan dalam penelitian ini adalah 32 perusahaan.

\subsection{Teknik Pengumpulan Data}

Sumber data dalam penelitian ini menggunakan sumber data sekunder. Sedangkan teknik pengumpulan data dalam penelitian ini menggunakan metode dokumentasi atau selecting document. Metode dokumentasi adalah metode pengumpulan data yang diambil dari dokuemn perusahaan berupa laporan keuangan dan laporan tahunan yang telah diaudit perusahaan perbankan yang terdaftar di Bursa Efek Indonesia (BEI) periode 2016-2020 di website resmi BEI www.idx.co.id

\subsection{Variabel dan Pengukurannya}

Tax Avoidance adalah praktik penghindaran pajak dengan cara melakukan pengecilan pajak yang masih bersifat legal. Dalam penelitian ini Variabel Tax Avoidane diukur dengan menggunakan proksi Effective Tax Rate (ETR) (Widodo et al., 2020).

$$
\mathrm{ETR}=\frac{\text { BEBAN PAJAK }}{\text { LABA SEBEUUM PAJAK }}
$$

Capital Intensity Ratio adalah rasio yang menggambarkan aktivitas investasi yang dilakukan oleh perusahaan yang dikaitkan dengan investasi dalam bentuk aset tetap (intensitas modal) Damayanti \& Gazali (2018). Dalam penelitian Rasio intensitas modal diukur dengan menggunakan proksi CIR (Mulyani et al., 2012).

$$
\mathrm{CIR}=\frac{\text { Total Aset Tetap }}{\text { Total Aset }}
$$

Ukuran perusahaan merupakan besar kecilnya perusahaan yang dapat dilihat dari jumlah asset yang dimiliki oleh perusahaan. ukuran perusahaan dalam penelitian ini diukur dengan rumus:

$$
\text { Ukuran Perusahaan= Total Aset }
$$

Kepemilikan Institusional adalah kepemilikan saham yang dimiliki oleh pemerintah, perusahaan asuransi, investor badan luar negeri atau bank (Dewi \& Jati, 2014) (Mulyani et al., 2012).

$$
\mathrm{KI}=\frac{\text { jumlah Saham yang dimiliki Institusi }}{\text { Saham Bereday }}
$$

\subsection{Teknik Analisis Data}

Penelitian ini menggunakan metode analisis regresi berganda dengan menggunakan software eviews 9, data diolah dengan menggunakan metode data panel yaitu menggunakan data cross section dan data time series. Metode analisis data penelitian ini meliputi: analisis diskriptif, analisis regresi berganda. Peneliti tidak menggunakan uji asumsi klasik karena dengan data panel maka implikasinya tidak harus dilakukannya pengujian asumsi klasik (Gujarati, 
2013). Berikut estimasi persamaan regresi penelitian ini: $Y=\alpha+\beta 1 X 1+\beta 2 X 2+\beta 3 X 3+\varepsilon$.; Keterangan $Y=T a x$ Avoidance; X1= Capital Intensity Ratio; X2 = Ukuran Perusahan; X3 =Kepemilikan Institusional

\section{HASIL DAN PEMBAHASAN}

Hasil Pengujian Statistik Deskriptif untuk variabel Tax Avoidance adalah sebagai berikut:

Tabel 1. Statistik Deskriptif

\begin{tabular}{lcccccc}
\hline Variabel & Obs & Mean & Median & Max & Min & Std.dev \\
\hline CIR & 160 & 0.029128 & 0.022334 & 0.112191 & 0.001510 & 0.022612 \\
UP & 160 & $1.86 \mathrm{E}+14$ & $3.99 \mathrm{E}+13$ & $1.42 \mathrm{E}+15$ & $1.97 \mathrm{E}+12$ & $3.17 \mathrm{E}+14$ \\
KI & 160 & 0.788477 & 0.750000 & 9.214213 & $2.00 \mathrm{E}-07$ & 0.833258 \\
TA & 160 & 0.252779 & 0.250691 & 1.000000 & 0.000807 & 0.126305 \\
\hline
\end{tabular}

Dari statistic deskriptif diatas dapat diketahui bahwa Capital Intensity Ratio menunjukkan angka rata-rata sebesar 0,029 dan standar deviasi sebesar 0,02. Ukuran Perusahaan Menunjukkan rata-rata sebesar I,86 dan sandar deviasi sebesar 3,17. Kepemilikan Institusional menunjukkan angka rata-rata sebesar 0,78 dan standar deviasi sebesar 0,83. Sedangkan Tax Avoidance menunjukkan angka rata-rata 0,25 dan standar Deviasi sebesar 0,12.

\subsection{Uji Multivariat (Uji Regresi Berganda)}

Analisis regresi pada penelitian ini menggunakan pengolahan data melalui eviews 9 adalah sebagai berikut:

Tabel 2. Hasil Uji Hipotesis

\begin{tabular}{lccll}
\hline \multicolumn{1}{c}{ Variabel } & Coefficient & Std. Error & t-Statistic & Prob. \\
\hline C & 0.263557 & 0.073822 & 3.570169 & 0.0005 \\
X1(CIR) & -0.007480 & 0.002346 & -3.187973 & 0.0018 \\
X2 (UP) & -0.001341 & 0.000885 & -1.514604 & 0.1324 \\
X3 (KI) & 0.008516 & 0.005007 & 1.701034 & 0.0914 \\
\hline
\end{tabular}

\subsection{Pembahasan}

Hasil penelitian menunjukkan beberapa temuan, Pertama Capital Intensity Ratio atau intensitas modal diukur dengan CIR menunjukkan bahwa Capital Intensity Ratio berpengaruh positif terhadap Tax Avoidance. Hasil temuan ini sejalan dengan penelitian dari Purwanti \& Sugiyarti (2017), Rahmawati (2019) dan Cahyani et al., (2021). Hasil penelitian yang dilakukan oleh peneliti menunjukkan nilai signifikan positif sebesar 0,0018 yang berarti H1 diterima, artinya capital intensity ratio berpengaruh terhadap tax avoidance. Capital Intensity Ratio merupakan rasio yang menggambarkan aktivitas investasi yang dilakukan oleh perusahaan yang dikaitkan dengan investasi dalam bentuk aset tetap. Rasio intensitas modal ini dapat menunjukkan tingkat efisiensi pada perusahaan dalam menggunakan aktivanya untuk menghasilkan penjualan. Intensitas modal dapat dijadikan teknik atau cara oleh perusahaan untuk menghindari beban pajak, hal ini dikarenakan manajemen pada suatu perusahaan dapat memanfaatkan dana yang menganggur untuk membeli aset tetap. Aset tetap tersebut akan mengalami penyusutan pada setiap tahunnya, sehingga akan menimbulkan beban penyusutan yang dapat mengurangi beban perpajakan pada perusahaan.

Kedua, variabel ukuran perusahaan yang di ukur dengan total aset perusahaan tidak berpengaruh signifikan terhadap tax avoidance hal ini sejalan dengan penelitian dari Susilowati et al., (2020). Hasil penelitian dari peneliti menunjukkan bahwa nilai signifikansi >0,05 yaitu sebesar 0,1324 yang berarti $\mathrm{H} 2$ ditolak. Ukuran perusahaan tidak berpengaruh terhadap praktik Tax Avoidane hal ini dimungkinkan bahwa perusahaan yang besar kegiatan operasional didalamnya juga besar. Oleh karena itu perusahaan memerlukan banyak dana guna mendukung aktivitas operasional perusahaan. salah satu cara yang dilakukan guna memenuhi pendanaan yaitu dengan hutang. Jadi meskipun perusahaan memiliki hutang bukan berarti perusahaan dengan sengaja menimbulkan biaya-biaya agar dapat meminimalisir pajak. Perusahaan melakukan hutang dikarenakan perusahaan benar-benar membutuhkan dana untuk menunjang keberhasilan perusahaan itu sendiri.

Ketiga, variabel kepemilikan institusional yang diukur dengan pembagian dari saham institusi dengan saham yang beredar menunjukkan bahwa kepemilikan institusional tidak berpengaruh terhadap tax avoidance. Hal ini sejalan dengan penelitian dari Winata (2014). Hasil penelitian dari peneliti menunjukkan bahwa nilai signifikansi $>0,05$ yaitu sebesar 0,0914 yang berarti H3 ditolak. Kepemilikan institusional tidak berpengaruh terhadap tax avoidance hal ini dimungkinkan bahwa, dengan adanya kepemilikan institusional maka akan menjadi pengawas bagi manajer dalam melakukan praktik tax avoidance. Kepemilikan institusional mempunyai peran penting dalam mengawasi manajemen perusahaan, karena dengan adanya kepemilikan institusional maka akan ada dorongan tingkat pengawasan yang lebih baik sehingga manajer tidak berani melakukan resiko dengan melakukan tax avoidance. 


\section{KESIMPULAN}

Berdasarkan hasil pengujian yang telah dilakukan dapat ditarik kesimpulan bahwa Hipotesis pertama (H1) dalam penelitian ini diterima artinya capital intensity ratio berpengaruh terhadap tax avoidance. Sedangkan Hipotesis 2 dalan penelitian ini ditolak, artinya ukuran perusahaan tidak berpengaruh terhadap tax avoidance. Dan hipotesis 3 dalam penelitian ini ditolak, artinya kepemilikan institusioal tidak berpengaruh terhadap tax avoidance pada perusahaan perbankan yang terdaftar di BEI pada tahun 2016-20221.

\section{REFERENCES}

Cahyani, A. Z., Djaddang, S., Sihite, M., Studi, P., Akuntansi, M., \& Pancasila, U. (2021). Faktor-Faktor Yang Mempengaruhi Tax Avoidance Dengan Tax Avoidance 2017-2019. 13(1), 122-135.

Cahyono, Andini, K., \& Raharjo. (2016). Pengaruh Komite Audit, Kepemilikan Institusional, Dewan Komisaris, Ukuran Perusahaan (Size), Leverage (Der) Dan Profitabilitas (Roa) Terhadap Tindakan Penghindaran Pajak (Tax Avoidance) Pada Perusahaan Perbankan Yang Listing Bei Periode Tahun 2011 - 2013. 2(2), 14-16.

Dewi, Ni Nyoman Kristiana; Jati, I. K. (2014). Pengaruh karakter eksekutif, karakteristik perusahaan, dan dimensi tata kelola perusahaan yang baik pada tax avoidance di bursa efek indonesia. 2, 249-260.

Hidayah, O. N., Masitoh, E., \& Dewi, R. R. (2020). Faktor-Faktor Yang Mempengaruhi Tax Avoidance Pada Perusahaan Pertambangan Di BEI. Jurnal Akuntansi Unihaz, 3(1), 66-79. https://journals.unihaz.ac.id/index.php/jaz/article/view/1333

Karim, A. (2017). p-ISSN 2086-3748. Jurnal Ilmu Manajemen Dan Akuntansi Terapan (JIMAT), 8(November), 64-79.

Moeljono, M. (2020). Faktor-Faktor yang Mempengaruhi Penghindaran Pajak. Jurnal Penelitan Ekonomi Dan Bisnis, 5(1), 103121. https://doi.org/10.33633/jpeb.v5i1.2645

Mulyani, S., Darminto, \& Endang, M. (2012). Pengaruh Karakteristik Perusahaan, Koneksi Politik Dan Reformasi Perpajakan Terhadap Penghindaran Pajak (Studi Pada Perusahaan Manufaktur Yang Terdaftar Di Bursa Efek Tahun 2008-2012). 262.

Purwanti, S. M., \& Sugiyarti, L. (2017). Pengaruh Intensitas Aset Tetap, Pertumbuhan Penjualan dan Koneksi Politik Terhadap Tax Avoidance. Jurnal Riset Akuntansi \& Keuangan, 5(3), 1625-1641.

Puspita, D., \& Febrianti, M. (2018). Faktor-faktor yang memengaruhi penghindaran pajak pada perusahaan manufaktur di bursa efek Indonesia. Jurnal Bisnis Dan Akuntansi, 19(1), 38-46. https://doi.org/10.34208/jba.v19i1.63

Rahman, F., \& Tjetje, N. F. (2018). Analisis Faktor-Faktor Yang Mempengaruhi Tax Avoidance. Jurnal Akuntansi Multi Dimensi (Jamdi), 1(1), 15-19.

Rahmawati, V. (2019). Pengaruh Size, Leverage, Profitability Dan Capital Intensity Ratio Terhadap Effective Tax Rate (ETR). Jrka, 5(2), 81-105. http://jurnalmahasiswa.stiesia.ac.id/index.php/jira/article/view/2362/2367

Setia, H. (2015). Pengaruh Frekuensi Pemeriksaan Pajak Dan Kualitas Pemeriksa Pajak Terhadap Tingkat Kepatuhan Wajib Pajak Badan. Jurnal Bisnis Dan Akuntansi, 17(1), 10-22. http://www.tsm.ac.id/JBA

Sugiyono. (2011). Metode Penelitian Kuantitatif, Kualitiarif, dan $R \& D$. Alfabeta.

Tebiono, J. N., \& Sukadana, I. B. N. (2019). Faktor-Faktor yang Mempengaruhi Tax Avoidance. Jurnal Bisnis Dan Akuntansi, 21(1a-2), 1211. https://doi.org/10.33087/jiubj.v20i1.808

Widodo, L. L., Diana, N., \& Mawardi, M. C. (2020). Pengaruh Multinasionalitas, Good Coorporate Governance, Tax Haven, dan Thin Capitalization Terhadap Praktik Penghindaran Pajak Pada Perusahaan Multinasional yang Terdaftar Di Bei Periode Tahun 2016-2018. E-Jra, 9(6), 119-133.

Winata, F. (2014). Pengaruh Corporate Governance Terhadap Tax Avoidance Pada Perusahaan Yang Terdaftar Di Bursa Efek Indonesia Tahun 2013. Tax \& Accounting Review, 4 (1)(1), 1-11. 